\title{
The Influence of Nested Type of Integrated Science Learning Model on Students' Critical Thinking and Cooperation Skills
}

\author{
Nurul Kamalia Habibah ${ }^{1}$, Allesius Maryanto ${ }^{2}$ \\ ${ }^{1,2}$,Study Program of Science Education, Faculty of Mathematics and Natural Sciences, Yogyakarta State University \\ Corresponding Author. Email: nurulhabibah1998@gmail.com
}

Keywords:
nested, critical
thingking skills,
collaboration skills

\begin{abstract}
The research aims to know the influence of the nested type of integrated science learning model on junior high school students' (1) critical thinking skills, (2) collaboration skills, and (3) the critical thinking skills and collaboration skills simultaneously. This research is a quasi-experimental study with a nonequivalent control group design. The population of this research is the whole class VII of SMPN 2 Godean. The sampling technique was cluster random sampling, so that class VII A was obtained as an experimental class, and class VII C as a control class. The learning in experiment class was conducted by using a nested type science integration model with a scientific approach, while the learning in control class with the scientific approach that teachers normally use in learning. The instruments used in this research are (1) pretest and posttest critical thinking skills, (2) collaboration skills observation sheets, and (3) learning achievement sheets. The analysis technique used is the independent sample t-test, manova test, and effect size. The result showed that there was a significant effect of learning the integration of nested science types on junior high school students' (1) critical thinking skills in the medium category, (2) collaboration skills in the medium category, and (3) critical thinking skills and collaboration skills simultaneously.
\end{abstract}

C2020 JSER. Yogyakarta State University

\section{INTRODUCTION}

Education in Indonesia is currently conducted based on the 2013 curriculum. According to the 2013 curriculum, natural science subject was developed as an integrated science subject that has disciplines in biology, physics, and chemistry. The natural sciences course is an educational program that is applicative-oriented and focuses on the development of thinking ability, learning ability, curiosity, development of caring attitude, and responsibility towards the environment and nature. Natural science courses use a trans-disciplinary approach where the boundaries of scientific disciplines are not visible. Since the concept of scientific discipline mingles with issues that must be learned about the environment and the natural surroundings, learning process becomes a contextual learning (Permendikbud number 35 of 2018 about the 2013 SMP / MTs curriculum). Integrated science learning gives students the opportunity to develop thinking, process, and social skills. Based on the observations of learning activities in SMP 2
Godean, it is known that learning process had not applied the concept of cohesiveness in terms of both the materials and the skills being trained. The learning process was still focused on delivering the materials instead of training the skills that must be mastered by the students in learning integration.

One of the skills that can be developed with integrated learning is critical thinking skills. Critical thinking skills are intellectual processes that form habits or abilities in conceptualizing, organizing, analyzing, collecting, and evaluating information into a unified form or producing something by observing, experiencing, reflecting, considering, or communicating as a belief and behavior (Snyder 2008: 98). Aspects of critical thinking include interpretation, analysis, evaluation, inference, explanation and self-reflection (Facione, 2015: 5-7). Critical thinking skills are important skills students have in the 21st century. Based on the 2015 PISA (the Program for International Student Assessment) report, the learners' ability of the 15-year age range 
(junior high school age) is still relatively low as showed by Indonesia's achievement which is ranked on the 62 position out of 69 countries. This data shows that Indonesia is still at a poor cognitive level because students' critical thinking skills are still low (Pratiwi, 2019: 58).

In addition to critical thinking skills, skills that can be developed with integrated learning are collaboration skills. Collaboration is to work together based on the same goal (Ningrum, 2018: 7). In cooperation, there is trust and working relationships between two or more participants involved in thinking, planning, and creating together clear instructions (Muttaqiyah, 2016: 4). Collaboration needs to be developed because students are not only required to learn independently but also learn in groups during the learning implementation. Based on the observations of learning activities in SMP N 2 Godean, it is known that students were still lack of collaboration skills. This could be known through practical activities and group discussions where the division of tasks, participation, and responsibilities of students is not yet clear. Not all students were involved in group activities.

One integrated learning model that supports learning activities in junior high schools and can develop students' critical thinking and collaboration skills is a nested type integrated learning model. Nested type integrated learning is a type of integrated learning that combines three skills, namely thinking skills, organizing skills, and social skills (Fogarty, 1991: 23). Nested type integrated learning model has not been widely applied in learning process. Although it strongly supports science learning activities in junior high schools, its application requires careful preparation. Therefore, this learning model is considered difficult.

The application of nested type integrated learning model can make learning activities more meaningful for students. Learning is more contextual since its process is more based on real problems that are often encountered by students (Prastowo, 2019: 39-41). Learning emphasizes students 'critical thinking skills and develops students' social skills, such as cooperation, tolerance, communication, and responsiveness to the ideas of others (Malawi et al, 2019: 4).

In its implementation, this nested type integrated learning model uses a scientific approach. Every step of the scientific approach is integrated with critical thinking skills, collaboration skills and organizational skills. Through a scientific approach, learning will be more meaningful. The learning process is designed to make students active in constructing concepts, laws, or principles through the stages of observing, formulating problems, collecting data, drawing conclusions and communicating (Machin, 2014: 31).

\section{METHOD}

This research used a qualitative approach. This type of research was quasi experimental. The type was chosen because it is very difficult to apply pure experiments in educational research which must control external variables that might affect the dependent variable. This research was carried out on January 21 - February 5, 2020, at SMP Negeri 2 Godean. The population of this study was all VII students of SMP Negeri 2 Godean in the 2019/2020 academic year, totaling four classes (VII A, VII B, VII C, and VII D). Research sampling used cluster random sampling techniques namely random sampling consisting of groups/clusters after the population is declared homogeneous. Samples were randomly taken by the lottery to determine the experimental class and the controlled class. Based on sampling obtained, class VII A was an experimental class, and class VII C was a control class.

The research design was a nonequivalent control group design. In this design, there were two groups chosen randomly in which the first group as the experimental class and the second group as the controlled class. Before the learning process was carried out, students were given a pretest to find out their initial abilities. After learning, students were given a posttest.

Table 1. Nonequivalent Control Research Design

Descriptions:

\begin{tabular}{cccc}
\hline $\mathrm{E}$ & $\mathrm{O}_{1}$ & $\mathrm{X}_{1}$ & $\mathrm{O}_{2}$ \\
\hline $\mathrm{K}$ & $\mathrm{O}_{3}$ & $\mathrm{X}_{2}$ & $\mathrm{O}_{4}$ \\
\hline
\end{tabular}

$\mathrm{E}=$ experimental class

$\mathrm{K}=$ controlled class

$\mathrm{O}_{1}=$ initial ability measurement of experimental group

$\mathrm{O}_{2}=$ final ability measurement of experimental group

$\mathrm{X}_{1}=$ distribution of nested type of natural science integrated learning model with scientific approach to experimental group

$\mathrm{X}_{2}=$ distribution of scientific approach which is usually applied by teachers to controlled group

$\mathrm{O}_{3}=$ initial ability measurement of controlled group 
$\mathrm{O}_{4}=$ final ability measurement of controlled group

The instruments used in this study included three subjects. The first was the questions of pretest and posttest critical thinking skills to determine the effect of nested type natural science integrated learning models on students 'critical thinking and cooperation skills. The second was the observation sheets to determine the effect of nested type natural science integrated learning models on students' collaboration skills. The third was the observation sheets of learning implementation to find out the percentage of learning achievement.

Data analysis techniques used in this study include the validity and reliability of the instrument, the prerequisite hypothesis test (normality and homogeneity test), independent sample t-test, manova test, normalized gain, and effect size. An independent sample t-test was used to determine whether there were differences in the critical thinking skills or collaboration skills of the experimental class and controlled class students. Manova test is used to determine whether there are differences in critical thinking skills and collaboration skills simultaneously in experimental class and control class students. The normalized gain calculation is used to determine the increase in students' critical thinking skills. Effect size is used to determine the magnitude of the effect of the nested type natural science integrated learning model on critical thinking skills or student collaboration skills. The impact value of effect size can be seen in the following table 2 .

Table 2. Cohen's Effect Size Criteria

\begin{tabular}{lll}
\hline Cohen's Standar & Effect Size & Persentase (\%) \\
\hline High & 2,0 & 97,7 \\
& 1,9 & 97,7 \\
& 1,8 & 96,4 \\
& 1,7 & 95,5 \\
& 1,6 & 94,5 \\
& 1,5 & 93,3 \\
& 1,4 & 91,9 \\
& 1,3 & 90 \\
& 1,2 & 88 \\
& 1,1 & 86 \\
Medium & 1,0 & 84 \\
& 0,9 & 82 \\
Low & 0,8 & 79 \\
& 0,7 & 76 \\
& 0,6 & 73 \\
& 0,5 & 69 \\
& 0,4 & 66 \\
& 0,3 & 62 \\
& 0,2 & 58 \\
& 0,1 & 54 \\
& 0,0 & 50 \\
\hline
\end{tabular}

Resource: (Becker, 2000: 3)

\section{RESULT}

In practice, nested type natural science integrated learning uses a scientific approach. Each scientific stage is integrated with indicators of critical thinking and cooperation skills. The use of this scientific approach can create more meaningful learning and students are more active in the learning process (Machin, 2014: 31).

The data on the results of the implementation of learning were obtained through observing the activities of the teacher and students during the learning process, using the learning implementation observation sheets which were adjusted to the Learning Implementation Plan (RPP). From the results of the percentage analysis of learning implementation using the percentage conversion guideline table, it can be seen that the learning process was carried out very well in accordance with the learning implementation plan. The following is the table of the learning implementation percentage: 
Nurul Kamalia Habibah, Allesius Maryanto/ JSER 2020, 4(1), 36

Table 3. Implementation of learning with a nested type of science integrated learning model

The Learning Implementation (\%)

\begin{tabular}{lccc}
\cline { 2 - 4 } & P1 & P2 & P3 \\
\hline Teachers & 94 & 100 & 94 \\
Students & 94 & 100 & 94 \\
Average & & 96 & \\
\hline Category & & Excellent \\
\hline
\end{tabular}

Critical thinking skills data were obtained through the pretest and posttest. The average value graph of students' critical thinking skills can be seen as follows:

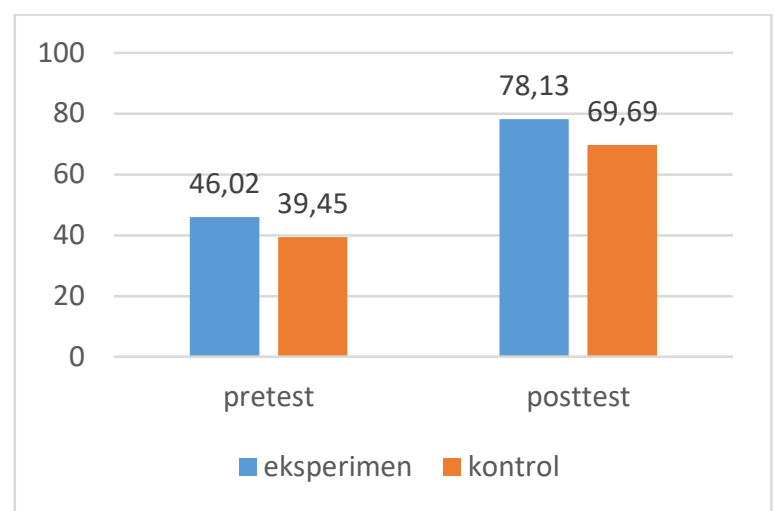

Figure 1. Average Value Graph of Critical Thinking Skills

Based on the graph in Figure 1, it is known that the experimental class has higher pretest and posttest scores than the controlled class. This shows that the experimental class has higher initial and final abilities than the controlled class. To find out the magnitude of the progress in the students' critical thinking skills before and after learning, the $\mathrm{N}$-Gain value was calculated. The following is the result of the average $\mathrm{N}$-Gain of the experimental class and controlled class.

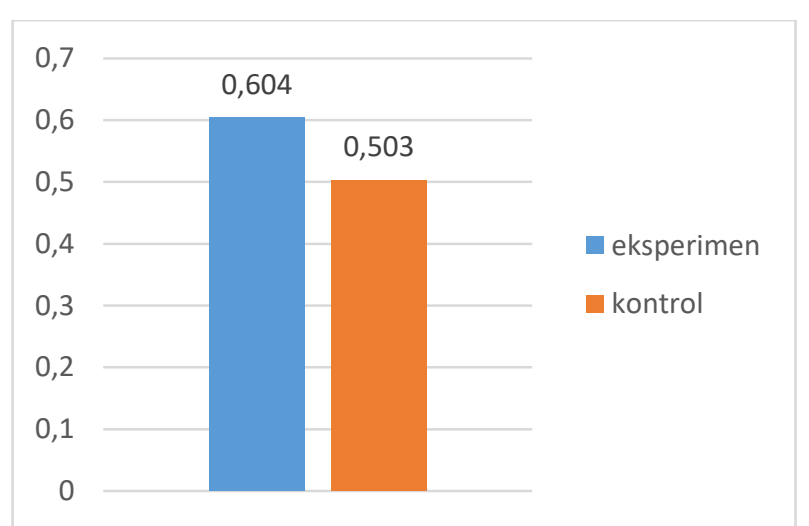

Figure 2. N-Gain Average Value Graph of Critical Thinking Skills

Based on the graph in Figure 2, it can be seen that the experimental class has a higher N-Gain value than the controlled class. This shows that the experimental class has increased critical thinking skills higher than the control class. The N-Gain values of both classes can be categorized into the medium category.

The decision making on the effect of nested natural science integrated learning on critical thinking skills was obtained from the results of the independent sample T-Test. It showed that there was a significant difference in the critical thinking skills of students in the experimental class and the controlled class. The differences can indicate the influence of using the nested type of natural science integrated learning model on students' critical thinking skills. The impact value can be seen through the calculation of the effect size. The result was 0.606 which can be categorized as high.

Learning with the nested type of natural science integrated learning model can improve critical thinking skills because students are guided 
to integrate the understanding of material concepts with thinking skills, especially critical thinking skills. In the learning process, students are required to be active in carrying out activities, so that learning becomes more meaningful. According to Yasin (2009: 3), integrated science learning that is presented can facilitate and motivate students to accept, recognize, absorb, and understand the relationship between these concepts and the values contained therein. Students will be trained to think broadly and deeply to understand the conceptual relationship of the materials.

In this study, students in the experimental class had higher critical thinking skills than those in the controlled class. This is because the implementation of nested type integrated learning uses a scientific approach that combines several skills. In each stage of the scientific approach, critical thinking indicators are trained to be achieved. The student worksheet used in the research also supports students to develop their critical thinking skills because it is prepared by developing the indicators of critical thinking skills.

Data on student collaboration skills were obtained through observing students' attitudes based on the observation indicators that had been compiled in the student observation sheet. Observations were conducted during three learning meetings. The average score of students' cooperation skills can be seen as follows:

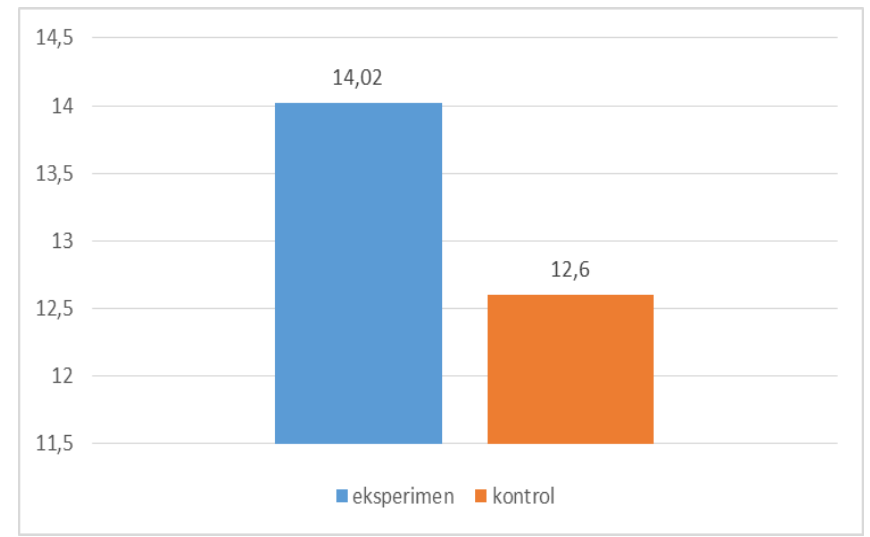

Figure 3. Graph of the Average Score of Collaboration Skills for the Experimental and Control Classes

Based on the graph in Figure 3, it can be seen that the collaboration skills of the experimental class are higher than that of the controlled class. The following is the average score for the aspects of collaboration skills:

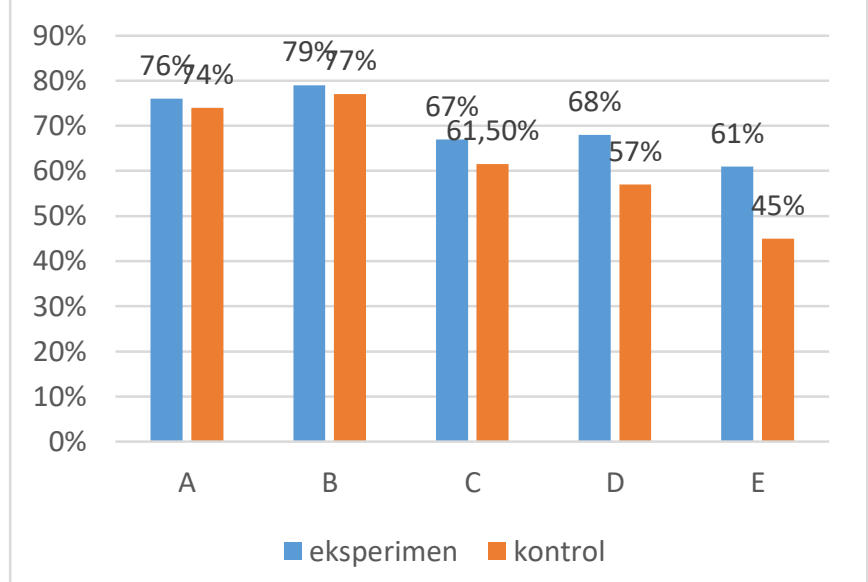

Descriptions:

Figure 4. Graph of the Average Score of Student Cooperation Skills Aspects

$\mathrm{A}=$ participating in carrying out the task

$\mathrm{B}=$ creating an atmosphere of collaboration in the group

$\mathrm{C}=$ exchanging the ideas with group members

$\mathrm{D}=$ helping each other

$\mathrm{E}=$ appreciating the results of group work

Based on the graph in Figure 4, it is known that the average score of the collaboration aspect of the experimental class students is greater than that of the controlled class. Based on the graph, the difference in the average score of students' cooperation skills in the experimental and control classes is only slightly. However, in the $\mathrm{E}$ aspect of 
appreciating the results of group work, it shows quite a lot of differences between the experimental and control classes. This is because there is an observation indicator of completing assignments on time. However, many controlled class students do not complete assignments on time. This shows that the experimental class time management is better than the control class. Good time management shows that cooperation in the group is good. In addition to time management, there is also an indicator of communicating the results of group discussions in front of the class. Students in the experimental class are more enthusiastic in communicating the results of the discussion in front of the class than the control class. Experiment class students voluntarily come to the front of the class to communicate the results of their group work. This shows that they value their group work and confidently show their group work to other groups. Unlike the case with the control class, even though it has been appointed by the teacher, students still do not show enthusiasm in communicating the results of their group work to the class.

The decision-making effect of the nested type of science integrated learning on cooperation skills was obtained from the results of the Independent Sample T-Test, which showed that there were significant differences in the cooperation skills of students in the experimental class and the control class. The existence of these differences can indicate the effect of using the nested type of science integrated learning model on students' cooperation skills. The amount of influence can be seen through the calculation of the effect size, the result is 0.701 which can be categorized as high.

Learning science with a nested type of science integrated model can improve students 'cooperation skills because in learning students are guided to carry out activities that can improve students' collaboration skills in groups. In learning, an integrated nested scientific approach is used, which in the scientific approach steps are integrated with collaboration skills. This integration is manifested in learning activities that can train cooperation skills, as well as being guided by LKPD which are prepared by developing indicators of cooperation skills. According to Abdulsyani (1994: 156), in cooperation, there are activities to achieve common goals by helping and understanding each other's activities which are the responsibility for achieving a common goal.

The decision-making effect of the integrated science learning model of nested type on critical thinking skills and cooperation skills was simultaneously obtained through the results of the Manova test which showed differences in critical thinking skills and collaboration skills of students in the experimental class and the control class. The existence of these differences indicates the influence of the use of integrated science learning model nested types on critical thinking skills and student cooperation skills simultaneously.

According to Wulandari et al (2015: 272), students' cooperation skills can affect students' critical thinking skills. With cooperation skills, students can better understand and be critical of a problem. In group learning activities, students who have high cooperation skills will have discussions with their group members, resulting in an exchange of ideas between group members, so that students can develop their thoughts from various points of view. In solving problems, students need critical thinking skills.

\section{CONCLUSION}

Based on the results of data analysis and discussion in this study, it can be concluded (1) there is a significant effect of using the nested type of science integrated learning model on the critical thinking skills of junior high school students in the moderate category, (2) there is a significant effect on the use of nested type integrated science learning model of junior high school students' cooperation skills in the medium category (3), there is a significant effect of using the nested type of science integrated learning model on critical thinking skills and junior high school student collaboration skills simultaneously.

Some suggestions that the researcher can convey after conducting this research are (1) the teacher is expected to implement a nested type of science integrated learning model in learning because it can improve students' critical thinking skills and cooperation skills, (2) this research is expected to be used for the development of educational research in the future, (3) this research is expected to be a consideration in facilitating and providing support for science learning..

\section{REFERENCES}

Abdulsyani. (1994). Sosiologi Skematika, Teori dan Terapan. Jakarta: Bumi Aksara.

Becker, L. A. (2000). "Effect Size Measures For Two Independent Groups." Web.Uccs.Edu 3. Diambil pada 15 Februari 2020, dari https://www.uv.es/ friasnav/EffectSizeBeck er.pdf

Facione, P. A. (2015). Critical Thingking: What It Is and Why It Counts? California: Measured Reasons LLC. 
Fogarty, R J. (1991). How to Integrate The Curricula. 3 ed. New Delhi: Corwin A Sage Company.

Kemendikbud. (2018). Peraturan Menteri Pendidikan dan Kebudayaan Republik Indonesia Nomor 35 Tahun 2018 tentang Perubahan Atas Peraturan Menteri Pendidikan dan Kebudayaan Nomor 58 Tahun 2014 tentang Kurikulum 2013 Sekolah Menengah Pertamal Madrasah Tsanawiyah.

Machin. (2014). "Implementasi Pendekatan Saintifik, Penanaman Karakter, dan Konservasi pada Pembelajaran Materi Pertumbuhan." Jurnal Pendidikan IPA Indonesia 3(1):28-35.

Malawi, I., Kadarwati, A., \& Dayu, D.P.K. (2019). Teori dan Aplikasi Pembelajaran Terpadu. Magetan: AE Media Grafika.

Muttaqiyyah, D., \& Arty, I.S. (2016). "Pengaruh Publikasi Tugas melalui STAD terhadap Kerjasama, Kreativitas, dan Prestasi Belajar IPA.” Jurnal Inovasi Pendidikan IPA 2(1):12.

Ningrum, M.F.P. (2018). "Upaya Meningkatkan Keterampilan Kerjasama Siswa pada
Bidang Studi IPA Melalui Penerapan Model Group Investigation Bagi Siswa Kelas 5 SDN Kumpulrejo 2." Wahana Kreatifitas Pendidik 1(3):7.

Prastowo, Andi. (2019). Analisis Pembelajaran Tematik Terpadu. 1 ed. Jakarta: Kencana.

Pratiwi, Indah. (2019). "Efek Program PISA terhadap Kurikulum di Indonesia." Jurnal Pendidikan dan Kebudayaan 4(1):51.

Snyder, L. G., \& Snyder, M.J. (2008). "Teaching Critical Thingking and Problem Solving Skills." The Delta Pi Epsylon Journal 2.

Wulandari, N. C., Dwijanto, \& Sunarmi. (2015). "Pembelajaran Model REACT dengan Pendekatan Saintifik terhadap Kemampuan Berpikir Kritis dan Kemampuan Kerjasama." Unnes Journal og Mathematic Education 4(3).

Yasin, Mujakir. (2009). "Implikasi Pembelajaran Sains Terpadu (Integrated Science Instruction) di SMP." INSANIA: Jurnal Pemikiran Alternatif Kependidikan 14(1):172-88. 